\title{
QUEERS ON ACCOUNT OF THE KINGDOM OF HEAVEN: \\ RHETORICAL CONSTRUCTIONS OF THE EUNUCH BODY*
}

\author{
J David Hester (Amador) \\ Guest Lecturer, Department of New Testament, Unisa \\ Interfakultäres Zentrum für Ethik in den Wissenschaften
}

\begin{abstract}
The body of the eunuch has been a source of tremendous rhetorical (not to mention social, moral, legal and political) contestation. In the ancient world, where the predominant "single-sex" model of human sexual identity and development demanded conformity to cleary differentiated roles between men and women, the eunuch transgressed this division. The purpose of the following paper is to explore the variety of ways in which the eunuch body was (and continues to be) confronted, constrained and defined by a "natural" heterosexist ideology striving to maintain its hegemony over sex-gender identity.
\end{abstract}

Keywords: Eunuchs, Castration, Heterosexism

The figure of the eunuch in Matt 19:12 has been interpreted (from as early as the $1^{\text {st }}$ century - as evidenced in the Matthean redaction) as a symbol for Christian chastity and celibacy. Modern interpreters, when they have bothered to consider the verse at all, have perpetuated the Matthean interpretation by viewing this verse within the context of the teaching on divorce in which it appears. ${ }^{1}$ However, both the awkward transition in Matt 19:10-11 and

The author would like to thank the National Research Foundation of South Africa and the University of South Africa for their generous support. The author would also like to thank the University of South Africa for inviting me as guest lecturer during the Summer of 2004 and for their sponsorship of the International Conference on Rhetoric and the Scriptures, which took place in Pretoria at that time, where my fellow rhetorical critics and South African colleagues were generously supportive of the research presented in this work. Finally, the Alexander von Humboldt Foundation provided the opportunity for the early stages of this research to take shape during my stay in Tübingen, Germany, at the Interfakultäres Zentrum für Ethik in den Wissenschaften.

$1 \quad$ Blinzler, J 1957. Eisin eunouchoi: Zur Auslegung von Mt 19.12. Zeitschrift für die neutestamentliche Wissenschaft und die Kunde der älteren Kirche 48:254-270. Luz, U 1985. Das Evangelium nach Matthäus, vol. 3: Mt 18-25. Zürich: Benziger Verlag, 103-112. Moloney, F 1979. Matthew 19, 3-12 and Celibacy. A Redactional and Form Critical Study. Journal for the Study of the New Testament 2:42-60. Gaechter, P 1963. Das Matthäusevangelium. Innsbruck: Tyrolia-Verlag, 617-618. Perdue, L 1986. The Wisdom Sayings of Jesus. Forum 2(3):3-35. Trautman, D 1966. The Eunuch Logion of Matthew 19,12: Historical and Exegetical Dimensions as Related to Celibacy. DST diss. Rome: Catholic Book Agency. Dupont, J 1959. Mariage et divorce dans l'évangile. Paris: Desclée de Brouwer. Quesnell, Q 1968. Made Themselves Eunuchs for the Kingdom of Heaven (Mt 19:12). Catholic Biblical Quarterly 30 (July):335-358. See also Donovan, M 1972. The Vicarious Power of the Church over the Marriage Bond. Rome: Catholic Book Agency, particularly 1648. Heth, W 1987. Matthew's “Eunuch Saying” (19:12) and Its Relationship to Paul's Teaching on Singleness in 1 Corinthians 7. PhD diss., Dallas Theological Seminary. Davies, M 1993. Matthew. Sheffield: 
the Matthean addition in 19:13 make it clear that Matthew's effort was a forced one. ${ }^{2}$ Additionally, the bizarreness of the saying itself renders it likely to have been an authentic tradition from the early Jesus movement. The conclusion that must therefore be reached is, this verse did not belong within the context Matthew set it in. ${ }^{3}$ The question that follows therefore is, within what other contexts might the saying have found resonance? This question breaks open a remarkable history before us, not just within the confines of early Christian practices of piety and devotion, but also within the larger contexts of gender ideologies and identities in the Ancient Eastern Mediterranean world.

Elsewhere I have detailed my arguments concerning the multiple interpretational trajectories that Matt 19:12 set off within early Christianity, ${ }^{4}$ and have suggested that such trajectories fundamentally undermine the heterosexist ideology at work behind current creation theological attempts to castigate and ostracize so-called deviant sexual activities, orientations and transgressive sex-gender identities. A dominical saying lifting up eunuchs, who were viewed as neither chaste nor celibate, radically undermines any call for heterosexist conformity within the church.

In this essay I wish to explore the ways in which the eunuch body was shaped through rhetorically constructed controversies regarding the eunuch's symbolic meaning within the gender economy of the ancient world. The eunuch's body was a site of incredible contention; it confronted a world in which the single-sex theory of human sex development demanded a clear and distinct dualism between the male and female. This distinction required constant rhetorical maintenance and reinforcement, since bodies could potentially slide from the male sex to other, inferior effeminate forms. In such a vulnerable system, the eunuch represented a sexed identity of confusion, disruption and transgression par

Sheffield Academic Press, 131-133. Moloney (1979) also accepts this reading in the context of the Sitz-imLeben Evangelium, arguing that it was directed specifically to new Gentile converts who were divorcing their unbelieving spouses. Schweizer, E 1975. The Good News according to Matthew. Translated by D Green. Atlanta: John Knox Press, 383-384. Morris, L 1992. Gospel according to Matthew. Grand Rapids: William B Eerdmans Publishing Company, 484-486. Sand, A 1986. Das Evangelium nach Matthäus. Regensburg: Friedrich Pustet Verlag, 391-392. Patte, D 1987. The Gospel according to Matthew. Philadelphia: Fortress Press, 266-268. Kodell, J 1978. The Celibacy Logion in Matthew 19:12. Biblical Theology Bulletin 8:19-23. Möller, F 1994. Matthäus: Kommentar. Vol. 2. Düsseldorf: Patmos Verlag, 275-276. Hill, D 1972. Gospel of Matthew. Pages 279-282 in New Century Bible. Edited by R Clements and M Black. London: Marshall, Morgan \& Scott. Willoughby, A 1907. Critical and Exegetical Commentary on the Gospel according to Matthew, International Critical Commentary. New York: Charles Scribner’s Sons, 203-206. France, R. 1985. Matthew. Tyndale New Testament Commentaries. Grand Rapids: William B. Eerdmans Publishing Company, 279-283. Countryman, LW 1988. Dirt, Greed and Sex: Sexual Ethics in the New Testament and Their Implications for Today. Philadelphia: Fortress Press, 150, 176. Dewey, A 1992. The Unkindest Cut of All? Forum 8(1-2):113-122. Countryman $(1988,150,176)$ relies on Malina, BJ 1981. The New Testament World: Insights from Cultural Anthropology. Atlanta: John Knox Press, 133, when he makes the claim that eunuchs are "intrinsically" individuals in the ancient world of dyadic personalities, i.e., without relationship to family. Dewey $(1992,113-122)$ rejects the Matthean redactional setting, but sees in the isolated logion a critique nonetheless of familial systems. See also Lenski, RCH 1943. Interpretation of St. Matthew's Gospel. Minneapolis: Augsburg Publishing House, 735-740, who views this saying as a call for sexual-mastery and self-control within marriage.

Dewey (1992, 113-122).

3 Funk, RW, RW Hoover and The Jesus Seminar 1997. The Five Gospels. The Search for the Authentic Words of Jesus. Sonoma: Polebridge Press, 220 - the Jesus Seminar voted this verse "Pink."

4 Hester, JD 2005. Eunuchs and the Postgender Jesus: Matthew 19:12 and Transgressive Sexualities. Journal for the Study of New Testament 28:13-40. 
excellence. As such, it not only exposed the limits of the sex system, but had to be controlled, constrained, and refashioned.

It is my purpose here to explore the ways in which bodies, societies, religion and rhetoric came and come together to maintain what is insisted upon as being a "natural" heterosexist division of the male and female. The anxiety exhibited when such an ideology confronts transgressive figures exposes both the artificiality and weakness of the system. ${ }^{5}$

\section{The Ambivalent and Contested Body}

\section{Herodotus, Histories 8.105-106}

Hermotimus [eunuch guardian of the sons of Xerxes], who came from this place Pedasa, had achieved a fuller vengeance for wrong done to him than had any man within my knowledge. Being taken captive by enemies and exposed for sale, he was bought by one Panionius of Chios, a man that had set himself to earn a livelihood out of most wicked practices; he would procure beautiful boys and castrate and take them to Sardis and Ephesus, where he sold them for a great price; for foreigners value eunuchs more than testicled men, by reason of the full trust that they have in them. Now among the many whom Panionius had castrated in the way of trade was Hermotimus, who was not in all things unfortunate; for he was brought from Sardis among other gifts to the king, and as time went on he stood higher in Xerxes' favor than any other eunuch.

Now while the king was at Sardis and there preparing to lead his Persian armament against Athens, Harmoniums came for some business ... [and] found Panionius ... Hermotimus, having got the man and all his household in his power, said to him: "Tell me, you that have made a livelihood out of the wickedest trade on earth! What harm had I or any of my forefathers done to you, to you or yours, that you made me to be no man, but a thing of naught? ...” With these words of reproach, he brought Panionius’ sons before him and compelled him to castrate all four of them, his own children ... which done, the sons were compelled to castrate their father in turn.

There are two important aspects worth noting about this, one of the earliest reports from Greco-Roman sources on the presence of eunuchs in the ancient world. The first is the horror and curiosity with which Herodotus recounts this tale. A rhetoric of tragedy suffuses the account, beginning with the narrator's introduction ("wrong done to him"), carried through to the voice of Hermotimus ("wickedest trade on earth," "a thing of naught”) and

See some of the more recent and outstanding examples of exploration into this area: Guyot, P 1980. Eunuchen als Sklaven und Freigelassenen in der griechisch-römischen Antike. Stuttgarter Beiträge zur Geschichte und Politik 14. Stuttgart: Klett-Cotta. Scholten, H 1995. Der Eunuch in Kaisernähe. Zur politischen und sozialen Bedeutung des praepositus sacri cubiculi im 4. und 5. Jahrhundert n. Chr. Frankfurt-am-Main: Peter Lang. Scholz, P 1997. Der entmannte Eros: eine Kulturgeschichte. Düsseldorf: Atemis \& Winkler. Browe, P 1936. Zur Geschichte der Entmannung: Eine Religions- und Rechtsgeschichtliche Studie. Breslaw: Müller and Seiffert. Riquet, M 1948. La Castration. Paris: P Lethielleux. Tougher, S (ed.) Eunuchs in Antiquity and Beyond. London: Duckworth Publishing. Brown, P 1988. The Body and Society: Men, Women and Sexual Renunciation in Early Christianity. New York: Columbia University Press. Keufler, M 2001. The Manly Eunuch: Masculinity, Gender Ambiguity, and Christian Ideology in Late Antiquity. Chicago: University of Chicago Press. All are excellent resources for the history of eunicism and castration in Late Antiquity.

6 Herodotus is among the earliest of Greek authors to use the word "eunuchos.” By the time of his writing, the etymological derivation of the word ("protector of the bedchamber") has already given way to the meaning “castrated” or “infertile man.” Cf. Guyot (1980, 20-21, footnote 13-16). 
culminating in the report-like description of the final act of forced castration. Such actions were associated in the Greek mind with tyrants. ${ }^{7}$ The eastern location of this story (one taking place in the house of Xerxes) only served to reinforce the repulsion with which the Greeks confronted their Persian enemy.

The second aspect, however, betrays the banality of the activity in which Panionius partook. Not only is it explained that castration of young boys was valued among foreigners "for reason of the full trust they have in them" (an oddly unexplained reason, suggesting an almost enthymematic quality to the sentence), but that such traffic in eunuchs was one supported by the Persian aristocracy and even the imperial household ("higher in ... favour than any other eunuch"). It is clear that although Herodotus is horrified by the story, its exceptionality lies in its ultimate outcome ("fuller vengeance ... than ... any man in my knowledge") and not necessarily the circumstances in which it takes place.

In fact, eunicism was an extremely widespread practice for centuries throughout the Eastern Mediterranean. Indeed, traditions regarding the socio-political origins of eunuchs traced the practice as far back as Queen Sammurat (809-806 B.C.E.) of Assyria, ${ }^{8}$ which, even if not true, ${ }^{9}$ suggests nevertheless that the practice of maintaining a eunuch bureaucracy was viewed by the ancients themselves as being extremely old. This practice continued in the East, eventually making its impact even upon the Roman Imperium in the West ${ }^{10}$ and carrying forward through Late Antiquity and into Byzantium. ${ }^{11}$

Eunuchs were commonplace, and yet exceptional. It is this ambivalence that defines them throughout the literature that mentions them. On the one hand, they held important positions in imperial bureaucracies of the Assyrian, Persian, Hellenistic and Roman Empires, becoming an important means by which these imperial households maintained their superiority over the aristocracy. They were luxury articles, ${ }^{12}$ highly desirable as servants and as lovers, fetching high prices ${ }^{13}$ not only for their presumed loyalty, but for

7 Cf. Homer, Odyssey 18.83ff.; Herodotus, Histories 3.49. By the time of Plato, Gorgias 473c the issue can be cited without specific details, and by the time of Juvenal, Satirae 10.306-307 and Flavius Philostratus, Lives of the Sophists 2.4.2 it is a rhetorical topos.

8 Cf. Ammianus Marcellinus, Res Gestae 14.6.17 “...beholding the troops of mutilated men, he would curse the memory of that Queen Semiramis of old who was the first of all to castrate young males...” "Ctesias” in Jacoby, F 1923. Die Fragmenta der Griechischen Historiker. Berlin: Leiden, 688 F1, mentions the presence of eunuchs during the reign Queen Semiramis.

9 The literature is complex and mixed. Note, "Hellanikos of Lesbos” in Jacoby (1923, 4 F 178), who attributes the introduction of courtly eunuchs to Queen Atossa.

10 Cf. Guyot (1980, 121-129), for a discussion of the presence of eunuchs in Rome in the early Imperium.

11 Here note the work of Ringrose, K 1996. Eunuchs as Cultural Mediators. Byzantinische Forschungen 23:7593. See also Ringrose, K. 1996. Living in the Shadows: Eunuchs and Gender in Byzantium. Pages 85-109 in Third Sex, Third Gender: Beyond Sexual Dimorphism in Culture and History. Edited by G Herdt. New York: Zone Books.

12 Part of their attraction was also necessarily due to their exotic origins: Once Domitian outlawed castration within the Empire (a law that was renewed throughout the following centuries, and never really consistently enforced), the trade in eunuchs from areas of the world beyond the Empires boundaries became the norm. Cf. the Codex Justinianus 6.42.2 - Leo forbids castration, but expressly allows trade in barbarian eunuchs.

13 Pliny the Elder, Natural History 7.129, mentions the sale of the eunuch Paizon for 500,000 sesterces; this appears to be an exception, however. Terence, The Eunuch 168 is the only other source that mentions the price for a specific eunuch (20 Minae). Justinian set a price structure for the sale of eunuchs: those under 10 years old - 30 solidi; over 10, but uneducated - 50 solidi; over 10 and educated - 70 solidi. Cf. Codex Justinianus 7.7.1.5. Guyot (1980, 28-36), has a discussion regarding the profitability of eunuchs as 
their sexuality. On the other hand, as we shall see, they were despised, vituperated by reference to the very reason they were desired and honored: As neither male nor female, they were arbiters of space (private and public), transgressors of sexual boundaries (male and female), and could move with impunity between social arenas that were exclusive to others (ruler and ruled).

Herodotus' account portrays precisely this ambivalence and the tensions and contestations that swirled around the eunuch body. The eunuch body of Hermotimus is both an entry into power and a thing of naught.

\section{The Third Sex}

Galen, On the Usefulness of Body Parts 14.6-7

Forthwith, of course, the female must have smaller, less perfect testes, and the semen generated in them must be scantier, colder, and wetter (for these things too follow of necessity from the deficient heat)... The testes of the male are much larger as he is the warmer animal. The semen generated in them, having received the peak of concoction, becomes the efficient principle of the animal. Thus, from one principle devised by the creator in his wisdom, that principle in accordance with which the female has been made less perfect than the male, have stemmed all these things useful for the generation of the animal: That the parts of the female cannot escape to the outside; that she accumulates an excess of useful nutriment and has imperfect semen and a hollow instrument to receive the perfect semen; that since everything in the male is the opposite [of what it is in the female], the male member has been elongated to be most suitable for coitus and the excretion of semen; and that his semen itself has been made thick, abundant, and warm...

\section{Cassius Dio, Roman History 76.14.4-5}

At home he [Plautanius] had one hundred noble Romans castrated, and none of us knew about it until after Plautanius had died... But he not only castrated boys and youth, but even men, including married men. His intention was that his daughter Plautilla, who later married Antoninus, should only have eunuchs for her servants and especially for her teachers in music and other fields of art. And so we looked on the very same people as both eunuchs and males, as both fathers and impotents, as both castrati and beard-wearers.

The eunuch body was a site of tremendous contestation and worry in a world where one sex required clear delineation of male and female realms. As a figure that was neither-nor, the eunuch represented a figure of the potential decay of this boundary, a point of terrible confusion.

This is nowhere better demonstrated than in the extreme variety of terms used in reference to them: The Greek corpus uses over $15,{ }^{14}$ the Roman over 20 terms ${ }^{15}$ to refer to

merchandise and an exploration of the typical costs. Throughout the $1^{\text {st }}$ through $6^{\text {th }}$ centuries eunuchs regularly fetched roughly four times the price of a regular slave.

14 Nouns include eunuchos (“eunuch”), spadon (“torn,” "removed”), ektomias (“cut out”), tomias (“gelded,” used dominantly with respect to animals), apokopos ("cut off”), thlibias ("pressed”), thalsias ("crushed”), and ithris ("eunuch”), none of which are loan words, translations, or transliterations. The Greek corpus also uses different verbs for “castrate”/ "make eunuch,” including apokoptō (“to cut off”), temnō (“to cut”), apotemnō (“to cut off”), ektemnō 
eunuchs/eunicizing. They are generally classifiable according to the various medical techniques of castration, and set within a widely employed differentiation between "natural" and "cut" eunuchs (even if this differentiation is not clearly defined). ${ }^{16}$ This confusion was compounded by the fear of being unable to identify eunicism with any certainty (at least in public). As Cassius Dio in Roman History reports, ${ }^{17}$ and as Lucian of Samosata's short satire The Eunuch suggests, the results of castration had differing effects depending particularly upon whether one was cut early in life ("natural"?) or later, making it difficult for anyone to be certain whether or not in a particular case the individual before one was, indeed, a eunuch. How "real" this difficulty was is not nearly as important than the belief that a "eunuch" might not be (and vice versa).

Among the reasons for this concern, the most interesting is found in reference to the medical treatises of the second through sixth centuries C.E. ${ }^{18}$ These treatises reflect concerns of patron patients (typically aristocratic in these circumstances) being addressed by their physician-authors, a concern regarding the protection of masculinity. In a world where the only thing that divided the male (socially superior) from the female (socially inferior) were levels of dryness and heat, men were concerned about the threat of effemination. Within the phallocentric gender economy of the ancient world, to be a man was to embody virtue. To be a penetrative male was to exercise the dominance required of masculinity and to embody the moral strength necessary to uphold honor. The possession of a penis and testicles was the sine qua non of morality and strength. But this was not enough. What we see in medical authors from (Aristotle and) Galen to Oribasius was a response to the fear of the loss of masculinity ${ }^{19}$ (and its related social consequences) and advice regarding its maintenance as informed by theories of sexed development that saw males and females as extreme developments of the same sex. ${ }^{20}$ Given this slippery slope

(“to cut out”), eunouchizō (“to castrate, to make a eunuch”), apospā̄ (“to tear from”), keirō (“to crop, cut off”), therizō ("to mow down, cut off”), among others. Cf. Guyot (1980, 23, footnote 25) for citations.

15 Verbs include abscidere ("to cut off, away”), abscindere ("to tear off, wrench away”), excidere ("to cut out”), percidere ("to beat or cut to pieces"), praecidere ("to cut short, mutilate”), recidere ("to cut back, lop away"), castrare ("to castrate"), emasculare ("emasculate"), eunuchiare ("to make a eunuch"), eunuchare ("to make a eunuch"), eunuchizare ("to make a eunuch"), eviriare ("to emasculate"), excastrare ("to emasculate"), desecare ("to hew off"), exsecare ("to cut out"), resecare ("to cut short") subsecare ("to cut away below"), adimere ("to take away”), amputare (virilia - “to emasculate”), eripere (virilitatem - "to emasculate”), frangere ("to shatter”), cf. Guyot (1980, 23, footnote 25). The Latin also adopted and transliterated terms from the Greek.

16 Cf. e.g., Adamantius, Physiognomy 2.3 - "The characteristics of natural ( $k$ k physeoos) eunuchs are worse that those of other men. So most of them are savage, deceiptful evildoers, each one more so than the last. Of the cut eunuchs (tomioon), though, some characteristics change over at the same time as the cut, but most of their congenital nature remains." Cf. also Pliny the Elder, Natural History 11.110, "Man is the only creature in which the testes are ever broken, either accidentally or by some natural malady; those who are thus afflicted form a third class of half men, in addition to hermaphrodites and eunuchs.”

17 Cassius Dio, Roman History 76.14.4-5.

18 See Galen, On Semen ( $2^{\text {nd }}$ century); Soranus, On the Diseases of Women ( $2^{\text {nd }}$ century); Oribasius, Collectio Medica ( $4^{\text {th }}$ century); Paulus Aegineta, Compendium Medici ( $6^{\text {th }}$ century); Caselius Aurelianus ( $5^{\text {th }}$ century).

19 Oribasius, Collectio Medica 22.2.20-22; Soranus, On the Diseases of Women 1.30-31; Galen, On Semen 1.16.19-31.

20 Cf. Laqueur, T 1990. Making Sex: Body and Gender from the Greeks to Freud. Cambridge: Harvard University Press. Medical theory stretching from Aristotle to Galen suggests that eunuchs represented the transformation of a male to a female, and this despite the fact that Galen critiques Aristotle on his understanding of this matter. Cf. Aristotle, Generation of Animals 4.1.766a-20-35, where he states that castration causes one to "change from the male to the female condition." Cf. Galen, On Semen 1.15.29-43; 
context where masculinity was always under threat of loss, the eunuch "naturally" became the embodiment par excellence of this loss.

After all, eunuchs had lost their masculinity. These were passive in the sex act, gave (and not received) pleasure, were submissive, and were mounted ("bottom"). These features described both women and slaves (male and female), and like them the eunuch was "infamia" - without legal standing. On the other hand, they were not women, unable to give birth or suckle. They were a monstrous identity formation that could move in between the rigid public-private zones of masculinity and femininity without fully embodying either or both sexed identities. In the words of the Historia Augusta, the eunuch body was a "tertium genus hominum" (a third sex, a third kind of human). ${ }^{21}$

\section{The Sexual/Sexy Transgressor}

\section{Lucian of Samosata, The Eunuch}

"[h]e declared it an ill-omened, ill-met sight if on first leaving home in the morning should set eyes on any such person. He had a great deal to say, too, on that score, observing that a eunuch was neither man nor woman, but something composite, hybrid, and monstrous, alien to human nature.”

As a monster, the eunuch body became the object of incredible vulnerability both rhetorically and therefore also physically. The terms used of them heaped scorn upon them. They were spoken of as effeminate, unmanly, immoderate, changeable (moody), lightskinned (reference to their life among women), weak, impotent, deceitful, cowardly and incapable of virtue. Popular novels ${ }^{22}$ depicted them as power seeking, unscrupulous, greedy, untrustworthy and undependable. A chreia attributed to Diogenes had him commenting upon an inscription over the door of a house of an "evil eunuch" that said, "Let nothing evil enter." His response: "How then can the owner enter?"23 Dream interpretation, ${ }^{24}$ popular sayings, ${ }^{25}$ fables ${ }^{26}$ even popular superstitions ${ }^{27}$ : All viewed the eunuch as an object of scorn, bad luck, and deception. The eunuch, by definition, was not (could not) be a morally upright and virtuous figure, but was always suspicious. ${ }^{28}$

1.16.15-18 where he speaks of the testicles of both men and women and how the removal of them causes them to lose their respective masculinity/femininity.

21 Historia Augusta, Severus Alexander 23.7.

22 Cf. Chariton, Chaereas and Callirhoe: Artaxates; Iamblichus, The Babylonian Story: Damas and Sakas; and Heliodorus, The Ethiopian Story: Euphrates, and many anonymous eunuchs.

23 Diogenes Laertius, Diogenese 6. The term “evil eunuch" is equivalent to "wicked witch" - one does not need to mention "evil," but does so out of a habituated labeling context.

24 Cf. Artemidorus Daldianus, Onirocritica 2.69.

25 Cf. Diogenianus 3.88 - "The eunuch has a prostitute" (in reference to someone who cannot follow through with something). Diogenianus 1.81 - "Every porcupine is rough" (in reference to the immoral character of eunuchs). Zenobius 2.62 - "You are a holy eunuch" (in reference to being a lightweight). Sirach 20:4 - "Like a eunuch lusting to violate a girl is the person who does right under compulsion."

26 Aesop fable Babrius 54 (=Perry 310) and 141 (=Perry 164). Cf. Giggs, L 2002. Aesop's Fables: A New Translation. Oxford: Oxford University Press.

27 Lucian of Samosata, The Eunuch; Claudian, In Eutropium 1.125.

28 With respect to eunuchs, during the period under question I have found very few examples in which a eunuch was praised. Ammianus Marcellinus, Res Gestae 16.7-4-9, gives Eutherius praise, but does so clearly 
This suspicion "naturally" extended to the sphere of sexual practices, where it was their status as "transgressor" that was of greatest concern. Their role in sexuality gave them their contested and contemptible identity. They were both passive receivers of male sexual activity, and active performers of giving (but not receiving) pleasure. ${ }^{29}$ They were adept at anal sex and fellatio, ${ }^{30}$ and were scorned for it. Even as objects of status and desire ${ }^{31}$ among aristocrats and rulers ${ }^{32}$ no "true" male wished to be or act like them. Indeed, those men who showed an inclination to continue the receiver role in homoerotic sexual relationship that they experienced during their early years as boys were castigated (called "pathici") for acting like eunuchs, ${ }^{33}$ and many even castrated themselves in an effort to retain position in such relationships and prolong their desirability. The fact of eunuchs as objects of sexual attraction rendered them vulnerable to oratorical attacks directed precisely at the sexual practices that made them so attractive. ${ }^{34}$

These accusations were not limited to the adeptness with respect to their male lovers alone. The reputation of eunuch sexual promiscuity also included giving sexual pleasure to their mistresses as well. ${ }^{35}$ These forms of pleasure included oral $^{36}$ and digital stimulation, but it was additionally suspected (or at the very least feared and rumoured) that penetration, though exceptional, was possible. ${ }^{37}$ Martial, ${ }^{38}$ Juvenal, $^{39}$ and Theophrastus ${ }^{40}$ report that

indicating that Eutherius was a unique figure in history. Lucian of Samosata, The Eunuch, has Lycinus repeat Bagoas' defense of himself wherein he referred to Aristotle's respect for the eunuch of Hermias, the tyrant of Atarneus, as well as a "certain Academic eunuch hailing from among the Pelasgians.” Polybius, History 22.22.1 praises Aristonikos. Eusebius, Church History 8.1.3-4, 8.6.5, praises the eunuchs under Diocletian, but this praise has to do with their willingness to embrace martyrdom. See also Xenophon, Cyropaedia 7.5.58, in which Xenophon portrays the reasons for Cyrus to institute a eunuch bureaucracy, with ambivalences such as "the eunuch, being degraded in the eyes of other men, is driven to seek the assistance of some lord and master" thereby attesting to their loyalty.

29 Cf. Petronius, Satyricon 1.23 for a bawdy example of a eunuch’s attempted sexual exploits.

30 Artemidorus Daldianus, Onirocritica speaks of fellators as those who have unclean mouths. Cf. 1.79; 4.59.

31 See Guyot (1980, 59-66), for an excellent summary of the presence of eunuchs as objects of sexual desire.

32 For the period of the ministry of Jesus and the writing of the New Testament texts, we note the presence of individual and sometimes quite influential eunuchs in the service of the Imperial families of Drusus, Claudius, Nero, Titus, Domitian, Marcus Aurelius, Commodus, Elagabulus, Severus Alexander, Gordian III. From the $4^{\text {th }}$ century onward, eunuchs had formed an integral part of the Imperial bureaucracy.

33 Note how the Historia Augusta, Commodus 1.7 accuses Commodus of being "both orally polluted and anally defiled.” Graffiti in Pompeii (cf. Corpus Inscriptionum Latinarum 4.1825-1827) accuses several individuals of being fellators and eunuchs, making it clear that the one was associated with the other, and just as clear that the individuals mentioned were probably neither. Historia Augusta, Elagabulus 5.2 spoke of that emperor, who was associated with the galli (though may not have been castrated), by reference to a simple question: "Who could endure an emperor who was the recipient of lust in every orifice of his body?" The general term "effeminate" (a whole semantic frame that included effeminatus, semivir, cinaedus, impudicus and pathicus) was used to refer to those males who favoured the passive role in sex, a term and a role that were widely associated with eunuchs for centuries. We will see further on how moralists viewed the desire to remain the recipient of a pederastic affair as a natural inclination toward effeminacy and eventually castration in order to maintain youthful beauty and appearance.

34 Claudian, In Eutropium book I, “details” the sexual exploits of Eutropius as the reason for his/her political success.

35 This reputation extends to the galli as well; cf. Lucian of Samosata, On the Syrian Goddess 22.

36 Cf. Martial, Epigram 3.81.

37 Note Terence, The Eunuch 642ff, where Dorus, a eunuch who has exchanged clothing with Chaerea, is initially accused by Phaedria of raping Pamphilia. Pythias, however, responds with confusion, "Why, faith, I had heard that they [eunuchs] were extremely fond of women, but were incapable; unfortunately what has 
women favored eunuchs, indeed even as marriage partners, particularly because the women could achieve sexual satisfaction without fear of pregnancy. ${ }^{41}$ Claudian hints at certain sexual (and shameful) intimacies that went on between eunuch and mistress. ${ }^{42}$ Jerome $^{43}$ and Tertullian ${ }^{44}$ both doubted that castration bridled any passion in them. ${ }^{45}$ Their suspicions are justifiable, insofar as accusations of adultery are reported, most notably in the Life of Apollonius of Tyana. ${ }^{46}$

Additionally, the intimacy with which eunuchs were able to share in the world of women made them vulnerable to other innuendos of immorality. Their role as intermediaries ${ }^{47}$ not only allowed women to enter into public spaces accompanied by eunuchs, ${ }^{48}$ but eunuch servants were also suspected of facilitating relationships between mistresses and their lovers behind their husbands' backs. ${ }^{49}$

All in all, the eunuch was seen as the embodiment of, and even the means of facilitating, sexual transgression.

\section{The Sacred Body}

\section{Lucian of Samosata, On the Syrian Goddess 50-51}

And on set days the multitude assembles in the sanctuary, and many gallo $i$ and the religious men that I spoke of perform their ceremonies; and they cut their own arms and beat one another on the back. And many stand there playing flutes and beating timbrels, and others sing inspired and holy songs. This is done outside the temple, and they who perform it do not come into the temple.

happened never came into my mind; otherwise I should have shut him up somewhere, and not have intrusted the girl to him.” Cf. also Juvenal, Satirae 6.366-377

38 Martial, Epigram 4.67, "Why does your Caelia have only eunuchs, Pannychus? Because she wants to whore it up, but not give birth." See also 3.81; 6.2, 21, 39, 67; 10.91; 11.81.

39 Juvenal, Satirae 6.366-377, suggests that women wait for the onset of puberty before sending their servants to be castrated by barbers, so that they can be sexually useful without worry about pregnancy. Cf. also 1.22.

40 Hieronymus, Adversus Jovinianum libri 2.1.47.

41 Tertullian, Ad Uxorem 2.8.4, “...mutilated for licentious purposes.”

42 Claudian, In Eutropium 1.105-109.

43 Hieronymus, Letters 107.11; 108.20.

44 Tertullian, Adversus Marcionem 1.29.

45 Basil of Ancyra in the fourth century On Virginity states, "It is said that those who, having attained virility and the age when the genital member is capable of copulation, have cut off only their testicles, burn with greater and less restrained desire for sexual union, and that not only do they feel this ardour, but that they think they can defile any women they meet without risk.” Quoted in Rouselle, A 1988. Porneia: On Desire and the Body in Antiquity. Oxford: Basil Blackwell, 123.

46 Flavius Philostratus, Life of Apollonius 1.33, 36. Note also Hermogenes, Concerning Stasis 4: A man discovers a eunuch with his wife and kills him; he is charged with murder.

47 For an excellent introductory exploration into the function of eunuchs as intermediaries, including reflections on the connection between eunuchs and angels, see Ringrose (1996, 75-93). Cf. also Scholz (1997, 162-172) and Guyot (1980, 130-176).

48 Hieronymus, Letters 22.16 (“crowds of eunuchs," “armies of eunuchs,” "troops of eunuchs,” surrounded aristocratic women when they went in public), 54.13; 56.13; 108.7.

49 Claudian, In Eutropium 1.85-89. See also Ovid, Amores 2.3.1. 
And on these days galloi are made. For while the rest are playing flutes and performing their rites, frenzy soon enters into many, and many there are who just came to watch who subsequently perform the act. I shall describe what they do. The young man whom Fortune has given to do this casts off his clothing and rushes into the center with a great shout, and takes up a sword, which has stood there many years for this purpose, I believe. Then he immediately castrates himself and runs through the City bearing in his hands those parts he has cut off. And from whatever house into which he shall cast these, he gets female clothing and womanly adornments. Thus they do when they castrate themselves.

\section{Tertullian, Monogamy 3}

[Jesus] stands before you, if you are willing to copy him, as a voluntary eunuch [spado typically translated here "virgin"] in the flesh.

Perhaps of greatest interest to biblical interpreters and students of religious history is that, despite the ambivalence (or perhaps because of it) the eunuch body suffered under rhetorically, the rites of passage practiced by religious movements tracing as far back as the roots of human civilization at Catal Huyuk included ritual castration as a religious act demonstrating devotion to Cybele (and eventually, in the synchretist world of the GrecoRoman Empires, the Magna Mater). These religious movements had been introduced into Rome 200 years before Jesus' ministry. Their popularity can be attested to not only by reference to the confusing breadth and variety of the religious myths of origins regarding its central figures (whether the Egyptian Isis-Osirus, Syrian Astarte-Tammuz, the Babylonian Ishtar-Dumuzi, or even the Greco/Roman Bacchus or Dionysius). Their influence can also be noted throughout the Mediterranean by reference to the numerous historical sources that mention both the religious myths and accompanying devotional practices (Pausanius, ${ }^{50}$ Arnobius, ${ }^{51}$ Ovid, ${ }^{52}$ Catullus, ${ }^{53}$ Apuleius, ${ }^{54}$ Philo, ${ }^{55}$ Livius, ${ }^{56}$ Lucretius, ${ }^{57}$ Lucian of Samosata, ${ }^{58}$ and Augustine, ${ }^{59}$ to name a few). Among its most famous adherents (or infamous, if you believe the Historia Augusta ${ }^{60}$ ) was the Syrian-born emperor Elagabulus (218-222 C.E.), whose efforts at religious reform called for the unification of all religious practices across the empire under the worship of the Mater Deum. Later, the emperor Julian (355-363 C.E.) attempted a similar reform. Indeed, it was not until the $5^{\text {th }}$ century that worship of the Mater Deum disappeared (or better: Was transformed into the worship of Mary).

Augustine, The City of God, especially books 2, 6, 7.

Historia Augusta, Elagabulus 18.14-33.7; compare, however, Herodian, Basileia Historia 5.5.5.

Ovid, Fasti 4.179, 212.

Catallus, Carmina 53.

Apuleius, Metamorphoses 7.25-30.

Philo, On the Special Laws 1.324-325; 3.37-42.

Livius, Roman History 29.14, 10.

Lucretius, On the Nature of Things 2.

Lucian of Samosata, On the Syrian Goddess.

Pausanias, Description of Greece 7.17.10.

Arnobius, Adversus Nationes 5.5. 
Christian devotees themselves similarly took up castration as a means of devotion to their religious calling. Based upon Matt 19:12, the literal reception of this saying was widespread among congregations in both the West and East, and the practice of castration continued for centuries. Valentinus, Julius Cassianus, ${ }^{61}$ Basilides ${ }^{62}$ Leontios of Antiochia, Melito "the Eunuch," Hilarion, Marcarius "the Egyptian" and Origen are among the most famous of many that chose to castrate themselves "on account of the kingdom of heaven.",63 One of the earliest testimonies we have of this practice comes from Justin Martyr in the early $2^{\text {nd }}$ century. ${ }^{64}$ Several early Christian encratite and ascetic movements had eunuchs among their members of a matter of course, and these same monastic communities in Egypt and Syria became centers of castration supporting the Byzantine and later Islamic empires for centuries. ${ }^{65}$ We should also note the eventual criminalization of eunuchs in the priesthood at the Council of Nicea (canon 1) ${ }^{66}$ viewing it rightly as testimony to the degree to which castration continued to be practiced among the orthodox devout. Indeed, eunuchs maintained their influence over the court in Late Antiquity, ${ }^{67}$ playing an important role in the history of both the state and church and maintaining a presence in both hierarchies for centuries. $^{68}$

The authority of Matt 19:12, coming as it was believed directly from the mouth of Jesus, coupled with a historical milieu that saw adherents of other religious movements castrate themselves as an act of religious piety, became a "difficult saying" that many early Christian males sought to fulfill literally on the basis of a "plain sense" reading of the text. For these Christian men, the body of the eunuch became witness to the depth of their commitment to the pursuit of the kingdom of heaven.

61 Cf. Clement of Alexandria, Stromata 3.13-14.

62 Cf. Clement of Alexandria, Stromata 3.1.1.

63 Cf. e.g., Epiphanius, Adversus Haereses 58 mentions the followers of Valens; one should also note possibility of castration practiced by Montanists and Marcionites.

64 Justin Martyr, First Apology 29, “And that you may understand that promiscuous intercourse is not among our mysteries, one of our number recently presented to Felix, the Prefect in Alexandria, a petition, asking that permission might be given to a doctor to make him a eunuch; for the doctor said that they were forbidden to do this without the permission of the Prefect. And when Felix would by no means agree to subscribe [to the persuasion] the youth remained single, and was satisfied with the testimony of his own conscience and that of his fellow believers.” The earliest report of eunuchs in Christianity is found in the Acts 8 of the Ethiopian eunuch. Interestingly, this pericope interested later interpreters only with respect to the question of the nature of the eunuch's conversion, and not with the status of the eunuch or the meaning of the state of castration.

65 Scholz (1997, 154-155).

66 Note the several loopholes: Council of Nicea 325 C.E., canon 1: "If anyone in sickness has undergone surgery at the hands of physicians or has been castrated by barbarians, let him remain among the clergy. But if anyone in good health has castrated himself, if he is enrolled among the clergy he should be suspended, and in future no such man should be promoted. But, as it is evident that this refers to those who are responsible for the condition and presume to castrate themselves, so too if any have been made eunuchs by barbarians or by their masters, but have been found worthy, the canon admits such men to the clergy.” [Italics mine.]

67 Note that this was the case despite several laws passed in the centuries beginning with Domitian (81-96 C.E.), reiterated by Nerva (96-98 C.E.), Hadrian (117-138 C.E.), and Constantine (306-337 C.E.) that made it illegal to make someone a eunuch in the Empire (and in the case of Hadrian's law, even if the individual were volunteering). Guyot (1980, 45-51), has an excellent discussion of the issue. Cassius Dio, Roman History 67.2.3, attributed the first law, issued by Domitian, to a political desire to insult Titus, who was said to be fond of eunuchs.

68 For an excellent introductory survey of the role of eunuchs in Byzantium, see Ringrose (1996, 85-109). 


\title{
The Morally Weak and Repugnant Body
}

\author{
Philo, On the Special Laws 1.324-325 [cf. Deut 23:1]
}

But while the law stands pre-eminent in enjoining fellowship and humanity, it preserves the high position and dignity of both virtues by not allowing anyone whose state is incurable to take refuge with them, but bidding him avaunt and keep his distance. Thus, knowing that in assemblies there are not a few worthless persons who steal their way in and remain unobserved in the large numbers which surround them, it guards against this danger by precluding all the unworthy from entering the holy congregation. It begins with the men who belie their sex and are affected with effemination, who debase the currency of nature and violate it by assuming the passions and the outward form of licentious women. For it expels those whose generative organs are fracture or mutilated, who husband the flower of their youthful bloom, lest it should quickly wither, and restamp the masculine cast into a feminine form.

The literal interpretation of Matt 19:12 was not uncontested during the first several centuries C.E. From as early as the Matthean redaction this instruction met with controversy. What is most often overlooked, however, is that the symbolic interpretation which eventually won out took several centuries before it would become the dominant orthodox reading. Those who advocated its position found themselves fighting against a "natural" reading of this verse whose advocates not only had the advantage of a "plain text" reading, but could also point to a history of eunicism as a devotional practice among eastern religions for centuries.

In order to combat this, those who advocated the allegorical reading of this verse drew from two primary resources to do so: (1) Their own rhetorical education; and (2) an appeal to the "naturalism" of masculinity and male sexed identity.

An excellent example of the first can be drawn, ironically enough, from the commentary on Matthew written by Origen in the early $3^{\text {rd }}$ century. ${ }^{69}$ Here he rejects two widely accepted interpretations of the text. The first he rejects quickly and summarily: Those who read this text literally are simply naïve. The second group, however, draws the greatest ire and energy from him: Those who read the first two types of eunuchs (those who were born that way, and those who were made that way by others) as literal references, while the third type (those who make themselves that way on account of the kingdom of heaven) is viewed figuratively. He poses a question to this second group: Would Jesus be such an inept rhetorician to mix up two rhetorical figures in the same saying? In Origen's eyes, Jesus' rhetorical skill would prevent him from switching tropes in the middle of a three-part klimax. Those who do not read the whole verse as a single allegorical trope both belittle Jesus' abilities and are guilty of beginning down the slippery slope of literalism. Such a group, indeed, is worse than the first, because the first group at least advocates an interpretation that has the advantage of consistency.

Origen's allegorical approach is hardly new. It drew from an Alexandrian school of interpretation whose methods were mostly famously practiced by Philo. Philo himself rejected castration, arguing that eunuchs are symbols of atheism, ones who were "cut off from wisdom.” Clement picks up upon this reading, as also Jerome after him, whereby castration is seen as the morally weaker choice: A "true" eunuch is not one who eliminates 
the ability to have sex, but one who eliminates the desire for sex (cf. Eusebius' Commentary on Isaiah and Athanasius' Orations against the Arians) ${ }^{70}$ As Jerome puts it, "Necessity makes another man an eunuch, my will makes me one." ${ }^{\text {,1 }}$ Eventually, this reading comes to dominate, even in the East where Gregory Nazianzos, ${ }^{72}$ Epiphanius, ${ }^{73}$ Eusebius, ${ }^{74}$ Athanasius ${ }^{75}$ and John Chrysostom ${ }^{76}$ would come to accept and advocate the allegorical reading of the text. The eunuch body is no longer a body witnessing to depth and extent of religious devotion, but rather to its moral weakness and inferiority.

The other resource advocates for a figurative, and/or allegorical reading of Matt 19:12 drew from is anticipated in the appeals to the betrayal of nature and the "disease of effemination" that the eunuch embodies. Philo made such an appeal in On the Special Laws (1.324-325; 3.37-42) and On the Contemplative Life (57-63). Here, the physical, medical and moral aspects of eunicism converge, where the loss of masculinity necessarily leads to immorality, excess of passion and the regrettable loss of procreative sperm "sown without purpose" (cf. Abraham 135). Josephus (Jewish Antiquities 4.292 [4.8.40]), from the same period and class location as Philo, also appealed to these very same concepts of "effeminacy," loss of masculine procreativity ("as if they had killed their children, since they beforehand have lost what should procure them") and "monstrous nature" when talking about eunuchs.

These tropes would suffuse later Christian apologetics, as Roman aristocratic male bishops sought to ensure their social equals that conversion to Christianity would lead to the fulfillment of the demands of masculinity. Eunicism in general threatened the already shaky foundations of Roman masculine identity; castration as an acceptable act of religious devotion was simply unacceptable. The call to be a "eunuch on account of the kingdom of heaven" had to be reinterpreted as a symbolic act of masculine askesis and rigor, one in keeping with medical theory and Middle Platonic and Stoic moral systems embraced by contemporary aristocratic Roman males. ${ }^{77}$ While the impulse leading to Christian castration was viewed as worthy, following through on the act could not be. The emasculated form of the eunuch that populated the religious landscape (both Christian and "pagan") had to become a scapegoat.

We see this best in the writings of Augustine, particular in City of God, where his invectives against the eunuch galli priests of Cybele are extremely harsh. Augustine speaks of "shameful rites" and "obscenities" that were "gross and immodest" (City of God 2.5) and "more unseemly than all scenic abomination." (City of God 6.7) To cast no doubt on what was troubling Augustine:

\footnotetext{
Cf. Eusebius, Commentarius in Isaiam 1.22 and 1.37; Athanasius, Orations against the Arians 1.27. Hieronymus, Letters 22.19.

Gregory of Nazianzus, Discourses 32-37.

Epiphanius, Adversus Haereses.

Eusebius, Ecclesiastical History 6.8.1, speaking on Origen.

Athanasius, Homily on the Song of Songs in Patroligiae Graecae vol. 27, col. 1332.

John Chrysostom, Homiliae in Genesim in Patroligiae Graecae vol. 58, col. 599.

Cf. Keufler (2001).
} 
But in whatever way their sacred rites may be interpreted, and whatever reference they may have to the nature of things, it is not according to nature, but contrary to nature, that men should be effeminates. (City of God 6.7)

Especially troubling is the gender blending that these priests represented to Augustine and others.

These effeminates [the galli] no later than yesterday, were going through the streets and places of Carthage with anointed hair, whitened faces, relaxed bodies, and feminine gait, exacting from the people the means of maintaining their ignominious lives. (City of God 7.26)

It was as much the outward appearance and feminine behavior of these priests as it was their physical emasculation that was most distressing, both combining to reinforce the sense of gender transgression. Additionally, the suspicion of sexuality was voiced ("ignominious lives”), referring to the consequences of eunicism: The loss of masculinity went hand-inhand with excesses of "unnatural" sexual acts. What was "unnatural" about them was that those who had been "men" had become "like women," that is, those who were (potentially) superior had become unavoidably inferior. This was something a conservative aristocratic male would find scandalous. The eunuch body is no longer a sign of an insufficient moral response to the dominical call, but is the embodiment of all this is socially, politically and morally repugnant: It is not male.

\section{The No-Body}

\section{Gagnon, The Bible and Homosexual Practice 176}

As far as the fittedness of the sex organs is concerned, only a woman is anatomically complementary to a man. For a man to take on that role is an obvious distortion of the gender distinctions endowed in nature by God.

As we end this brief excursion into the kaleidoscopic forms of the contested eunuch body, one additional form is worth mentioning here. In the modern world, the body of the eunuch simply does not exist. This is true at a cultural-discursive level, as many of the traditional social contexts in which eunuchs found their support and location no longer exist. It is true in a medico-discursive level, as castration is a practice rarely utilized and rarely mentioned, except perhaps in juridical contexts. It is also true in religio-discursive level, especially in Christianity today, where the flagrantly transgressive quality of the eunuch, the full contestation of that identity in the ancient world, is simply ignored. When Matt 19:12 is discussed, the eunuch as a symbol of chastity and celibacy is seemingly "obvious"; most controversies regarding this verse either view it as advocating celibacy after divorce, or view it as rejecting marriage and family-kinship systems altogether. The eunuch is not a eunuch at all, but a man who chooses celibacy.

I wish to suggest that modern Christian acceptance of this interpretive approach is premised upon a completely ideological misreading of eunicism altogether. It presumes that since a eunuch cannot procreate, a eunuch must be celibate. However, the only way in which one equates the physiological incapacity for procreativity with the physiological incapacity for sex, is through an ideological presumption that understands sex as necessarily the penetrative act of a male penis into the vagina of a female for procreative purposes. According to such an ideology, no other form of sex can (or should) exist. Here we see the limits of "nature" and the ideological machinery at work to ground heterosexism in creation. 
One obvious victim of such ideological efforts is the (modern) homosexual, since nonprocreative and non-heterosexual sex is "contrary to nature." Using language reminiscent of the ancients, modern Christian biblical scholars, theologians and sexual moralists who advocate on behalf of the proscription of homosexuals/-ity in the church make frequent use of rhetorical strategies that homosexuality is contrary to nature ${ }^{78}$ and God's law, ${ }^{79}$ and have even made reference to the social and psychological consequences of such activity. ${ }^{80}$ With the disappearance of the eunuch body, the only sexual identities left within God's design are male and female; any other form of sexual practice, or any alternative identity that does not conform to the heterosexual binary exclusivist paradigm, is unnatural and unholy.

To restore the eunuch body is to be forced to ponder more deeply the implications and consequences of the direct connection Jesus makes between this contested body and the kingdom of heaven. These consequences have a profound impact upon us, not only as religious devotees within the Abrahamic tradition, but also as people with assumptions about ourselves and gender. On the one hand, for Jesus to lift up this particular body, this transgressive, contested and ambivalent identity as representative of the impact of the kingdom of heaven upon the sex-gender identity of the believer is to throw into question the very issue of the "naturalness" of the male/female binary. It is to sensitize us to the presence of a rhetorolect in the Bible that indeed rejects this very binary as inessential for Christian identity. Galatians 3:28 and the triple tradition controversy story with the Sadducees concerning the resurrection are at least two examples of canonical testimony to an alternative tradition that counters heterosexism as God-ordained and necessary.

On the other hand, to reintroduce the eunuch body to modern discussions of sexuality is also to force us to become sensitive to the history of human controversy concerning what constitutes a "natural" sex identity, and our responses to those who do not conform to our beliefs regarding it. Modern homosexual identities, transgenders and transsexuals, even the intersexed: Each face tremendous social (not to mention religious and legal) sanction. The question is: If heterosexuality is so "natural," why are we so concerned to force it upon people?

Ultimately, the body of the eunuch is the site of tremendous anxiety, an anxiety that forces us to ask, how are we who we are as sexed beings?

78 Gagnon, R 2001. The Bible and Homosexual Practice: Texts and Hermeneutics. Nashville: Abingdon.

79 Seitz, C 2000. Sexuality and Scripture's Plain Sense: The Christian Community and the Law of God. Pages 177-196 in Homosexuality, Science and the "Plain Sense” of Scripture. Edited by D Balch. Grand Rapids: William B Eerdmans Publishing Company.

80 Jones, S and M Yarhouse 2000. The Use, Misuse, and Abuse of Science in the Ecclesiastical Homosexuality Debates. Pages 73-120 in Homosexuality, Science and the "Plain Sense" of Scripture. Edited by D Balch. Grand Rapids: William B Eerdmans Publishing Company. 